\title{
ABOUT PHYSIOLOGICAL AND MORPHOLOGICAL PROCESSES IN POULTRY AT NATURAL AND INDUCED MOLTING
}

\section{V.I. FISININ, A.P. KONOPLEVA}

All-Russian Research and Technological Poultry Institute, Federal Agency of Scientific Organizations, 10, ul. Ptitsegradskaya, Sergiev Posad-11, Moscow Province, 141300 Russia, e-mail fisinin@vnitip.ru Received May 8, 2015

\begin{abstract}
Plumage is a characteristic feature of birds. Feathering as a cutaneous derivative is a complex structure with specific mechanism of formation. Functions of plumage are thermal regulation, mechanical protection of bird's body and flight. Color and form of feathers in different parts of the bird's body could also serve as sexual characteristics. Molting in adult birds depends on season of a year, age of birds and management conditions as well. The process of molting is closely associated with reproductive function. A change in management conditions can induce full or partial molting in chicken, ducks, geese, turkeys, and guinea fowl. Stress factors can also induce molting thus affecting the productive cycle in poultry. Molting is a complex biological process. The change of feathering occurs as a result of altered interactions between endocrine glands of the body including pituitary, thyroid and sex glands. An influence of the hormones released by these glands on the molting-related metabolic processes is mediated by central nervous system (I.C. Dunn et al., 2009). The resulting morphological and physiological alterations allow a manipulation of the reproductive function to optimize timing and intensity of lay in females and sperm production in males. The data are presented to specify the processes in meat-type hens and cocks exposed to molt-inducing factors (A.P. Konopleva et al., 1976; Sh.A. Imangulov et al., 2000; P.F. Surai et al., 2012). The molting was induced by technological, chemical or hormonal factors. On days 7, 30 and 60 after the exposure to a moltinducing factor the condition of pituitary and thyroid gland body heat production, $\mathrm{Ca}$ and thyroxin levels in serum were recorded. Molting related alterations substantially influenced digestibility of dietary nutrients, fat deposition in body and egg productivity in laying hens. Stressed cocks responded to stress factors rather with significantly lowered sperm production than with molting. The result is a 3-5\% decrease in egg fertility in the second productive period. The layers ceased the lay and started the second productive period in 45-60 days. The intensity of lay in this second period reached $60 \%$, its duration was 6 months. The chicks hatched from molted layers were found to be more livable if compared to the first productive period. The comparison of different methods of molting induction showed the technological approach to be more effective if compared to chemical or hormonal factors. The alterations disclosed during artificially induced molting in modern meat-type chicken strains were found similar to those in less productive poultry reported in special literature earlier.
\end{abstract}

Keywords: poultry, chicken, stress factor, endocrine glands, pituitary, thyroid gland, hormones.

One of the crucial factors of efficient poultry egg and meat production is the duration of the productive use of mature stock. Due to successful selection efforts, egg-type hens can lay 300 to 310 eggs per year [1]. Further, however, the costs of growing one laying hen in a parent or commercial stock account for a substantial share in the prime cost of laid eggs. Therefore, extending the productivity period of adult layers to $90-120$ weeks is considered as a reserve way to reduce egg production costs. According to I.C. Dunn [2], an increase of 25 eggs in the laying capacity will make it possible to reduce the number of hens in England by 2.5 million per year. The number of eggs from laying hens can be increased by extending the period of their use. If the productive period is extended by 10 weeks, nitrogen consumption decreases by $1 \mathrm{~g}$ per each dozen of eggs, which also reduces environmental pollution [3]. For this reason, selection is required both for the intensity of egg production throughout life, and for the lon- 
gevity of reproduction functions in laying hens.

The selection for increased laying capacity is based on the fundamental knowledge of the functional specifics of the bird's reproduction system.

Laying hens are known to synthesize and to lay $4 \mathrm{~g}$ of protein in the egg and $5 \mathrm{~g}$ of calcium carbonate in the eggshell [4]. These components are synthesized under the influence of gonadotropins produced due to the interaction of endocrine signals of the hypothalamus and the hypophysis in the brain. In turn, steroid hormones produced by the hen ovary effect the growth and development of the oviduct. Thus, according to P.J. Sharp et al. [5], the weight of hen oviduct grows from 4 to $40 \mathrm{~g}$ by its puberty. With reduced production of steroid hormones as a result of adverse factors, the oviduct loses the gained weight and diminishes [6]. According to I.C. Dunn [2], the production of steroid hormones decreases as a result of lower activity of the hypothalamic-pituitary-testicle axis.

The deviations occurred in the hen's body are manifested in reduced laying intensity and poorer morphological qualities of eggs. This is accompanied by a change in the biological qualities of eggs expressed in reduced hatchability of fertilized eggs [7-9]. As layers grow, the intensity of the stimulating impact of the hypothalamus decreases making the pauses in egg production longer. It is especially typical of meat-type hens [10].

Induced molting is one of the ways to prolong the periods of hen use. However, this technique requires in-depth studying of the processes going on in a bird during molting.

The plumage condition (along with weight) refers to the outer manifestation of physiological changes both in adult birds and in young stock during breeding. The mechanisms of plumage change and the interrelation of this process with the poultry productivity are of a big scientific and practical interest. Plumage change may be followed by molting, i.e. fall of old and growth of new feathers requiring much forage energy.

Feathering as a cutaneous derivative has a complex structure and a specific mechanism of formation. Throughout life, plumage changes in different age periods. Full or partial change of plumage depends not only on age, but on environmental conditions as well. In particular, the time of plumage change in wild birds directly depends on climate factors and seasonal migration. For poultry (hens, turkeys, guinea fowl) natural plumage change (molting) is more related to age, while for ducks and geese it also depends on the year season [11, 12].

Plumage formation in birds starts in embryo, on the days 4-9 in hens [12]. Neoptile starts to form on the week 2 of development on various parts of the body and looks like a transformed apex of juvenile feathering in hatched chicks. Feathering, or neoptile, is formed in a feather follicle [13]. Each feather follicle gives rise to three plumage phases, i.e. down, or original feathering, prepenna, or juvenile feathering, and adult, or definite, feathering.

Replacement of down for juvenile feathering and prepenna, and then for adult feathering is generally called molting.

The interest in studying the mechanisms of plumage change is conditioned upon the objective dependence between the physiological state of the organism and the effect of molting on the performance of poultry [14]. The nutrient density of diet, the kill age, and the period of productive use of hens to get hatchable and edible eggs cannot be determined without regard to the physiological changes caused by molting. Moreover, the phenotypic assessment of selection birds first of all takes into account their plumage condition. Furthermore, the external manifestation of problems with the stock caused by a disease or wrong feeding is the plumage condition [13]. On young highly productive egg-type hen crosses and on ducks, Yu.Ya. Markov (15) and O.D. Ko- 
tova [16] proved a relation between the weight at a 2 and 3 months' age and the number of old flight wing feathers.

In our opinion, molting in modern highly productive poultry crosses and lines is studied insufficiently. Most research works on molting mechanisms (V.F. Larionov in 1930-1945; G. Streich and E. Svetozarov in 1932-1950; A.A. Voitkevich in 1945-1960) were done based on investigations in low productive poultry $[12,13,17,19]$.

These and many foreign scientists devoted their numerous researches to identifying the mechanism of plumage change and the physiological changes that accompany and provoke various molting stages [12, 17-19]. A special focus was on investigating effects of the thyroid functions on the plumage change. A.A. Voitkevich ascertained that in bird ontogenesis the first phase of the transformation process (neoptile development with simultaneous formation of feather buds) precedes the thyroid functioning period. However, thyroid hormones are assumed to have a crucial effect both on further juvenile and seasonal molting. Summarizing his own and other scientists' research, the author singles out a triad of thyroid organs whose hormones are dominant for the formation and change of plumage. They are the pituitary, thyroid and sexual glands. The hormonal function of the thyroid and sexual glands depends on the activity of the anterior pituitary [12].

The effect of hormones on metabolism is mediated by the nervous system the functions of which depend on the external environment, first of all light and temperature factors [19]. Feeding conditions are also essential for molting. Thus, with a deficiency of manganese, iodine, sulfur, vitamine $\mathrm{B}_{3}$, and certain aminoacids, plumage change delays, and with a deficiency of methionine and cystine new plumage won't not grow at all [18]. So, the in-depth study of the processes going on in birds during plumage change leads to the conclusion that molting is a manifestation of their adaptation to the environment. The connection with the environment is through the nervous system that regulates the internal physiological reactions.

The interrelation between the plumage change and the reproductive function served as the basis for the attempts to prolong the productive period of poultry through artificially induced molting. To that end, various methods were used, such as administration of thyroid hormones, progesterone, and various chemical agents [20]. Artificial stressing by means of light, temperature and food factors is of special significance.

In physiological terms, stress is a deviation from optimum environment conditions, including the external conditions of poultry management. Stresses may lead both to a deterioration of reproductive qualities and to a drop in productivity. Depending on the strength of stress, the organism either handles it or dies [14]. In the conditions in question, appropriate actions should be taken for the birds to respond to stress factors with their plumage drop, or molting, and with reduction or loss of their reproductive functions, but without irreversible physiological consequences.

Professor K. Sukhomlin et al. [22] conducted research on White Leghorn hens aged 11.5, 13.5 and 19.5 months. The stress syndrom was studied by blood serum indicators, the energy potential in muscles, liver, and ovary was estimated by ATP activity, and also protein fractions, $\mathrm{Na}, \mathrm{K}$, and $\mathrm{Ca}$ in organs and tissues, carbohydrate, fat and protein metabolism indicators were assessed. Three and ten days' starvation was used as a stress factor. A high correlation was established between the reducing capacity of blood serum and the laying ability.

It should be noted that stresses that cause induced molting generally 
contribute to the mobilization of internal body reserves, as well as increased oxidation, energy and protein synthesizing potential that ensure a repeated enhancement of laying qualities and increase the resistance of hens and their breed and improve their reproductive qualities [22-26].

The experiments on Plymouth rocambole hens and Cornish cocks of the parent broiler stock (All-Russian Research and Technological Poultry Institute) were conducted with the main objective to study the functional and morphological changes in meat-type hens during molting induced by means of various methods. Three groups were formed by the principle of analogs. In group I, there was the poultry stressing by deprivation of food, water and light (zootechnical method); in group II molting was induced by feeding premix (1\%) containing Evertas (Czechoslovakia) (chemical method); in group III a single intramuscular introduction of progesterone with plolongatum (hormonal method) was used. Thyroxine (thyroid hormone) and calcium content in blood serum, gas metabolism indicators, mass and microstructure of endocrine glands and the histologic skin structure were determined before molting and after 7, 15, 30, 45 and 60 days after the exposure to stress factors. At the same time, laying ability, live weight, feed consumption and utilization were taken into account. In repeated research only the zootechnical method of stressing was used.

It was demonstrated that live weight of hens reduced by the day 30 from the commencement of stress factors, and then recovered almost to the initial values by the day 60 . Food consumption by hens reduced significantly at the beginning of molting and increased during the recovery period reaching the initial values by the day 60 from the beginning of stress exposure. During molting, the use of compound feed nutrients reduced. The most rapid plumage change (fall of old feathers and growth of new flight and covert feathers) was observed after the introduction of progesterone.

Anatomic and physical indicators in Plymouth rocambole hens and Cornish cocks of the parent broiler stock during molting (All-Russian Research and Technological Poultry Institute, Moscow Province)

\begin{tabular}{|c|c|c|c|c|c|}
\hline \multirow{2}{*}{ Indicator } & \multirow{2}{*}{ Group } & \multirow{2}{*}{$\begin{array}{l}\text { Before } \\
\text { molting }\end{array}$} & \multicolumn{3}{|c|}{ Molting from the beginning of stress exposure, day } \\
\hline & & & 7 & 30 & 60 \\
\hline \multicolumn{6}{|l|}{ Weight, mg: } \\
\hline \multirow[t]{3}{*}{ Ovary } & I & 60.0 & 35.0 & 15.0 & 70.0 \\
\hline & II & 46.0 & 12.0 & 5.0 & 64.0 \\
\hline & III & 37.0 & 12.0 & 4.0 & 64.0 \\
\hline \multirow[t]{3}{*}{ Thyroid gland } & I & 250.0 & 230.0 & 260.0 & 370.0 \\
\hline & II & 277.0 & 235.0 & 350.0 & 323.0 \\
\hline & III & 256.0 & 352.0 & 330.0 & 335.0 \\
\hline \multirow[t]{3}{*}{ Pituitary gland } & I & 15.0 & 17.2 & 19.0 & 21.0 \\
\hline & II & 16.0 & 15.6 & 17.0 & 20.0 \\
\hline & III & 17.0 & 16.0 & 17.0 & 21.3 \\
\hline \multirow[t]{3}{*}{ Adrenal } & I & 280.0 & 485.0 & 208.0 & 300.0 \\
\hline & II & 256.0 & 312.0 & 240.0 & 273.0 \\
\hline & III & 256.0 & 351.0 & 331.0 & 336.0 \\
\hline \multicolumn{6}{|c|}{ Plasma concentration, $\mathrm{mg} \%$} \\
\hline \multirow[t]{3}{*}{ Thyroxine } & I & 20.8 & 19.5 & 9.9 & 8.6 \\
\hline & II & 17.9 & 18.2 & 16.0 & 10.0 \\
\hline & III & 19.8 & 9.7 & 11.9 & 11.9 \\
\hline \multirow[t]{3}{*}{ Calcium } & I & 14.2 & 13.7 & 11.0 & 20.8 \\
\hline & II & 16.2 & 12.8 & 11.6 & 22.1 \\
\hline & III & 14.1 & 12.0 & 10.5 & 18.9 \\
\hline \multirow[t]{3}{*}{ Respiratory coefficient } & I & 0.69 & 0.65 & 0.67 & 0.70 \\
\hline & II & 0.68 & 0.65 & 0.66 & 0.70 \\
\hline & III & 0.70 & 0.66 & 0.66 & 0.69 \\
\hline \multirow{3}{*}{$\begin{array}{l}\text { Total heat production, } \\
\mathrm{kcal} / \mathrm{kg} \cdot \mathrm{h})\end{array}$} & I & 3.96 & 4.13 & 4.44 & 3.12 \\
\hline & II & 3.32 & 3.73 & 3.82 & 2.98 \\
\hline & III & 3.64 & 3.48 & 3.86 & 3.40 \\
\hline
\end{tabular}


The birds' hypophysis weight increased insignificantly during molting, and the thyroid weight reduced by the day 7 of exposure to stress factors and then grew by the days 30-60 (Table). The adrenal gland weight recovered by the day 60 , the ovary weight reduced by the day 30 from stress commencement, but exceeded the initial values by the day 60 . It should be noted that in birds exposed to hormonal stress, as compared to birds exposed to Evertas, and alimentary and light factor, the thyroid weight increased and the ovary weight decreased more substantially by the days 7 and 30 .

In some cases, the concentration of thyroxine in blood serum grew insignificantly by the day 7 and then reduced to the minimum value by the day 60 from stress commencement. By the day 30 from the beginning of stress exposure, the calcium content in blood serum reduced against the initial value, and exceeded it recovering by the day 60 . The most significant changes in the blood content of thyroxine and calcium were in birds stressed by progesterone. Similar changes were observed for the respiratory coefficient. On the day 30 after stress exposure, the overall heat production was the highest, which was determined by a significant heat loss from the body areas free from plumage.

The histologic research shows that during molting the basophil cells grew in number and volume in the adenohypophysis of birds producing thyroidstimulating hormone. By the day 60 , after the end of molting, basophil cells reduced to the initial number. During molting, the thyroid gland was hyperactive with prevailing middle follicles and high cylindrical epithelium and multiple resorption vacuoles in colloid. By the day 30 and especially by the day 60 , the number of large follicles stretched by colloid increased with a higher intensity of coloring, which evidences the normalized gland structure and functions.

At the beginning of molting, the cortical layer prevailed over the medulla in the adrenal gland as a result of the increased number of cells, the volume of their nucleus and cytoplasm, which evidenced the increased functional activity. By the day 30, the cortical layer area reduced, and there were cells with a decreased function. Their number increased by the day 60 . The microscopic structure of adrenal glands in various molting periods makes it possible to conclude that first the function of the cortical layer cells strengthens and then weakens (by the day 30 and especially the day 60).

During molting, the ovary function changed. During the initial period, large and middle vitelline follicles degenerated and reduced in volume, or atrophied, until the day 30. Then the ovary blood supply improved and vitelline follicles grew with accumulation of vitelline material. By the day 60, the ovary looked almost typical of the functioning body.

The study of the cutaneous covering showed that by the day 7 from the beginning of molting, the skin blood supply deteriorated. The blood vessels were collapsed and did not contain blood corpuscles. In some feather follicles feather buds were formed. In the epithelial case of such follicles, the malpighian layer cells reproduced, while the corneous layer remained unchanged, and the cells in the epidermal papilla activated. In the upper part of the epidermal papilla, cells were sparse. Blood vessels started to grow in the space between them. In the lower part of the papilla, there were compactly located fibroblast-type cells. By the day 30, skin blood supply improved. Blood vessels were well-defined, and their lumens contained blood corpuscles. The transformation process was intensive. Many chest and back feathers were already formed. Their growth and differentiation continued. At the same time, many new feathers were formed on the neck. By the day 60, the growth and differentiation of feathers generally completed. Thus, the fall of old feathers and the growth of new feathers depended on the skin blood supply and the supply of skin cells with nutrients. 
The research results enable the authors to conclude that during forced molting induced by food and light deprivation, Evertas and progesterone, meattype hens experience functional and structural changes the intensity of which is determined by the force and duration of stress factors.

The initial molting period is characterized by reduced consumption and use of food nutrients, especially nitrogen, the activization of basic metabolism, increased release of heat and endogenous nitrogen, enhanced pituitary, adrenal and thyroid functions, depressed genital apparatus and cessation of egg laying, skin destruction, intensive loss of feathers, and reduction of live weight.

The morphological restructurings in endocrine glands and skin, the intensity of plumage loss, the changes in the blood level of tyroxine and calcium and heat production were even more evident during the initial molting period in hens exposed to progesterone and Evertas. During the recovery period, the functions and structure of endocrine glands and skin, and the activity of gas, energy and calcium metabolism normalized, the anabolic processes prevailed over catabolic, the live weight increased and laying began (within the same period in all groups studied).

When explaining the molting mechanism in birds, researchers lay stress upon the thyroid hyperfunction and the ovary hypofunction [12, 17, 19]. In their opinion, hyperthyrosis causes the activation of feather papilla and the formation of new feathers contributing to the fall of old ones, while hypoestrogenemia reduces the activity of old feather bags. As our research shows, during the period of initial molting induced in hens by food and light deprivation, Evertas and progesterone, the thyroid function is really activated, which is followed by increased synthesis and release of thyroxin into the internal environment, depression of the ovary activity and the atrophic processes prevailing in skin over the reparative ones.

However, as it follows from the research data, the triggers of induced molting are conditioned upon the functional state of the hypophysis regulated (through the hypothalamus) by the nervous system that adapts the organism to stress factors inducing molting. Through the nervous system, the stress factors had an effect on the functional condition of the adenohypophysis, the basophil cells of which enhanced the synthesis of thyrotropic and adrenocorticotropic hormones in eosinophilic cells. Increased release by the adenohypophysis of thyrotropic hormone into the internal environment ensured higher synthesis and secretion of thyroxin by the thyroid gland. Thyroxin, in its turn, caused the activation of metabolism, reduction of live weight, formation of new and fall of old feathers. In hens, the blocking of the gonadotropic hormone secretion by the anterior pituitary at the beginning of molting depresses the synthesis of sex hormones by the ovary and further leads to laying cessation.

Increased release of the adrenocorticotropic hormone by the hypophysis during the initial molting period leads to increased synthesis and secretion by the adrenal cortex of gluco- and mineralocorticoids ensuring adaptation in stress conditions.

Thus, the obtained data show that modern highly-productive meat-type hens preserve the same regularities of physiological condition during molting as identified in birds with low performance.

During the initial molting period, hens completely lost plumage, consisting primarily of protein (up to $85 \%$ ), and live weight. The changes in the bird's body led to the cessation of egg laying. The laying ability recovered by day 45 from the beginning of stress exposure, and after 60 days the intensity was $60 \%$ with substantially higher egg weight. The chickens hatched by second-year hens were more vital and had higher growth rates. At the same time, the brood of 
chickens was 3-5\% less than before stressing.

Studying the effect of stress factors on Cornish male parent cocks of the parent broiler stock revealed lowered sperm production after stressing. Natural molting in Cornish cocks starts 2-3 months earlier than in hens. After full or partial molting, cocks do not respond with feather drop to all of the molt induction methods used. Sperm production in molting cocks does not cease. Sperm production is noted to depend more on the plumage condition than on age. The correlation factor between the sperm volume and the spermium content in cocks for the period from week 26 to week 60 and in the second productivity cycle is generally positive and amounts to 0.5-0.6. However, the sexual activity of cocks reduces with age more sharply. It evidently has an adverse effect on egg fertilization. Such dependence was also observed earlier $[23,25,26]$.

To improve induced molting, methods should be found to bring the birds out of molting to ensure high productivity in the next cycle [27, 28]. Moreover, the appropriate methods are to be developed for waterfowl, guinea fowl and turkeys to prolong their productive period.

So, in an environment of modern commercial poultry production the induced molting has not lost its value and is extensively used both in the production of edible eggs, and by reproduction farms, especially by egg plants. Using induced molting as a technique is efficient with respect to high-performance special poultry crosses due to the following reasons. First, molting can be used to plan egg production subject to seasonal demand. Second, which is especially important, molting makes it possible to reduce three-fold the number of young poultry to complete a productive stock, which will save food, energy sources and labor input on breeding. And third, molting can help reproduction farms to reduce their costs on purchasing hatching eggs. Moreover, induced molting can serve as a tool to correct process failures due to objective reasons. There are various methods of exposure used for poultry to induce molting. The most effective, however, is stressing using feeding and watering regimes in combination with light factors. It is supposed that the physiological and morphological changes in egg-type and meat-type poultry are similar to those described above. The extent of their manifestation is determined by the starvation time, and the changes in the diet before stressing and during molting

\section{REFERENCES}

1. Da m m e K., Simon I., Flock D.K. Adaptability of laying hens to different environments: analysis of German random sample tests 2010/11 with floor management and enriched cages. Lohmann Information, 2012, 47: 9-14.

2. D u n n I.C. Long life layer: genetic physiological limitations to extend the laying period. Proc. 19th European Symposium on Poultry Nutrition (August 26-29, 2013). Potsdam, Germany, 2013: 25-26.

3. Dunn I.C., Cic cone N.A., J o se ph N.T. Endocrinology and genetics of the hypothalamic-pituitary-gonadal axis. In: Biology of breeding poultry. P.H. Hocking (ed.). CAB International, 2009.

4. Dougherty D.C., S a nders M.M. Estrogen action: revitalization of the chick oviduct model. Trends Endocrinol. Metab., 2005, 16: 414-419 (doi: 10.1016/j.tem.2005.09.001).

5. Sharp P.J., Dunn I.C., C e rolini S. Neuroendocrine control of reduced persistence of egg-laying in domestic hens - evidence for the development of photorefractoriness. J. Reprod. Fertil., 1992, 94: 221-235 (doi: 10.1530/jrf.0.0940221).

6. Nys Y., Guy o t N. Egg formation and chemistry. In: Improving the safety and quality of eggs and egg products. Y. Nys, M. Bain, F. Van Immerseel (eds.). Cambridge, Woodhead Publishing, 2011.

7. Willi a ms K.C. Some factors affecting albumin quality with particular reference to Haugh unit score. World's Poult. Sci. J., 1992, 48: 5-16 (doi: 10.1079/WPS19920002). 
8. Wolc A., White I.M.S., Hill W.G., Olori V.E. Inheritance of hatchability in broiler chickens and its relationship to egg quality traits. Poult. Sci., 2010, 89: 2334-2340 (doi: 10.3382/ps.2009-00614).

9. Wolc A., Arango J., Settar P., O'Sullivan N.P., Olori V.E., White M.S., Hill W.G., Dekkers J.C.M. Genetic parameters of egg defects and egg quality in layer chickens. Poult. Sci., 2012, 91: 1292-1298 (doi: 10.3382/ps.2011-02130).

10. Cic cone N.A., S harp P.J., Wils o n P.W., D u n n I.C. Changes in reproductive neuroendocrine mRNAs with decreasing ovarian function in ageing hens. Gen. Comp. Endocrinol., 2005, 144: 20-27 (doi: 10.1016/j.ygcen.2005.04.009).

11. Van Khe-min'. Ptitsevodstvo, 1959, 4: 25-27.

12. Vo it k e vi c h A.A. Pero ptitsy [Plumage in birds]. Moscow, 1962.

13. L a ri o n o v V.V. Uchenye zapiski $M G U, 1945,88: 58-65$.

14. Ko chish I. Zhivotnovodstvo Rossii, 2007, 6: 15-17.

15. M a rk ov Yu.Ya. Prognozirovanie produktivnykh kachestv kur yaitsenoskikh linii na osnovanii izucheniya protsessov rosta i smeny pera. Kandidatskaya dissertatsia [Prediction of production performance in hens of egg-laying lines based on growth and molting. PhD Thesis]. Moscow, 1973.

16. Kotova O.D. V sbornike: Uspekhi zootekhnicheskikh nauk [In: Advances in zootechnic science. V. 2]. Moscow, 1936, tom 2: 475-486.

17. Svet o z a rov E., Shtraikh G. Uspekhi sovremennoi biologii, 1943, 12(1): 25-51.

18. I m a $\mathrm{ngul}$ o v Sh.A., D o g a d a e a I.V., Kavt a r a s h i li A.Sh. Sel'skokhozyaistvennaya biologiya [Agricultural Biology], 2000, 6: 86-89.

19. Sveto z a rov E., S ht ra i h G. Uchenye zapiski MGU, 1940, 24: 392-396.

20. Y a m o m o to T. Referativnyi zhurnal VNIITEISKH (Moscow), 1973, 11: 22.

21. S u ra i P.F., F is i n in V.I. Materialy XVII konferentsii VNAP «Mirovoe zhivotnovodstvo: vyzovy budushchego» [Proc. XVII WSAP Conf. «Animal Husbandry in the World: Challenges of the Future»]. Sergiev Posad, 2012: 24-34.

22. Sukhomlin K., K at ri ch N., D mitrienko S. Ekspress-informatsiya VNITIP, VNITEISKH (Zagorsk), 1976, 3: 20-23.

23. K a p usti n E. Ptitsevodstvo, 2013, 4: 9-10.

24. S a vits k i i F.P., K o n o p l e v a A.P. Trudy VNITIP (Sergiev Posad), 1997, 72: 8-13.

25. K o n o p le v a V.I., K o n o p l e v a A.P. Prinuditel'naya lin'ka kak metod povysheniya vosproizvoditel'noi sposobnosti ptitsy. Metodicheskie rekomendatsii po biologicheskim osnovam povysheniya produktivnosti sel'skokhozyaisvtennoi ptitsy [Forced molting to increase reproductive performance in poultry: recommendations on biological bases of improvement production efficiency]. Erevan, 1987.

26. K o n o p lev a A.P., F is i n i n V.I. Trudy VNITIP (Zagorsk), 1976, 40: 12-17.

27. F is i n i n V.I., K o n o ple va V.I., K o n o p leva A.P. Materialy konferentsii VASKHNIL «Zhivotnovodstvu - promyshlennuyu osnovu» [Proc. Conf. «Commercial Bases for Anumal Husbandry»]. Moscow, 1978: 49-58.

28. Fis i n i n V.I., S tolly a r T.A., I mangulov Sh.A., Kavt a rashvili A.Sh., B e b i n M.L., S a mo i lova L.F., Markov Yu.Ya., Kozhe myaka N.V., N a i d e nski M.S., Bondarev E.I., Komilov D.K., Polyakov G.K., Osipova A.P., Akatov A.E., S o k o lov V.V. Prinuditel'naya lin'ka kur: Metodicheskie rekomendatsii [Forced molting in hens: manual]. Sergiev Posad, 1997. 